\title{
Pyroclastic density currents associated with the 2015 phreatomagmatic eruption of the Kuchinoerabujima volcano
}

\author{
Nobuo Geshi* ${ }^{*}$ and Jun'ichi Itoh
}

\begin{abstract}
A pyroclastic density current (PDC) was observed with the phreatomagmatic eruption of the Kuchinoerabujima volcano, southern Japan, on May 29, 2015. The PDC flowed down in all direction from the source crater, forming three major branches. The PDC reached the western coast of the island and the edge of the habitation area, which is $\sim 2.4 \mathrm{~km}$ away from the source crater. The average speed of PDC along the Mukaehama River was estimated as $42 \mathrm{~m} / \mathrm{s}$. The PDC involved both surge and block-and-ash flow. Pyroclastic surge left thin layer of volcanic ash, though no remarkable signature of the lateral transportation was found in the surge deposit. The surge deposit occupies $85 \%$ of the area covered with the PDC. Block-and-ash flow deposits were also recognized, but their distribution was limited mainly at the foot of the steep slope of the edifice of Shindake. The erupted materials from the May 29, 2015 eruption were estimated to be $\sim 1.3 \times 10^{9} \mathrm{~kg}$, including $2.4 \times 10^{8} \mathrm{~kg}$ of the PDC deposit and $\sim 1.1 \times 10^{9} \mathrm{~kg}$ of the fallout deposit in proximal and distal area. The PDC deposit consisted of rock fragments with various degrees of hydrothermal alteration. The least-altered glassy blocks of andesite, which was the candidate for the juvenile materials, occupied less than $10 \%$ of the deposit. The area covered by the PDC was damaged by both mechanical and thermal effects. The dynamic pressure of the PDC damaged the forest in the inner portion of the area covered with the PDC. The thermal influence of the PDC caused dieback of the vegetation and deformation of some plastic materials. The absence of carbonization of wood in PDC indicates that the temperature was below the ignition temperature of wood. These observations suggest that the temperature of the PDC was between 100 and $240-270{ }^{\circ} \mathrm{C}$.
\end{abstract}

Keywords: Pyroclastic density current, Pyroclastic surge, Phreatomagmatic eruption, Kuchinoerabujima volcano

\section{Introduction}

Phreatic eruption is characterized by explosive extrusion of pressurized geothermal fluid to the ground surface due to instability of the hydrothermal system. Although the magnitude of phreatic eruption is relatively small, phreatic eruption is the most frequent type of eruption and can be hazardous to areas proximal to the erupting site (Fujinawa et al. 2008). Lack of clear precursors for the phreatic eruption sometimes makes the prediction of phreatic eruptions difficult and resulted in several serious accidents such as those observed at Mt. Ontake in 2014 (Oikawa et al. 2016).

\footnotetext{
*Correspondence: geshi-nob@aist.go.jp

Research Institute of Earthquake and Volcano Geology, AIST, 1-1-1 Higashi, Tsukuba, Ibaraki 305-8567, Japan
}

Active geothermal areas at shallow depth have a potential of phreatic eruptions because of the instabilities in hydrothermal activities. Minor layers of tephra deposits commonly found near the geothermal area [e.g., Owakudani geothermal area of the Hakone volcano (Kobayashi et al. 2006)] indicate the repetition of phreatic eruptions from active geothermal system. Despite their frequent occurrence and the potential risks, phreatic eruptions remain poorly described, because of poor preservation and indistinctive features of the deposits.

Phreatic eruptions often generate a pyroclastic density current (PDC), which is characterized by wet flow with relatively low temperature (McPhie et al. 1990; Lube et al. 2014). Phreatic PDCs are highly hazardous to humans who are involved in the flow, even though the size of PDC associated with phreatic eruption is generally smaller and 
the temperature is much lower than those of the magmatic PDC (Fujinawa et al. 2008).

In this study, we describe the PDC of the Kuchinoerabujima volcano, which occurred on May 29, 2015, as an example of a small but locally violent PDC associated with the phreatomagmatic eruption. The 2015 eruption of Kuchinoerabujima volcano showed a phreatomagmatic feature with a low contribution of the molten magma. The PDCs caused mechanical and thermal damages such as wide destruction and dieback of the vegetation in their path, leaving only a minor deposit. This paper reports the nature of the PDC from the 2015 eruption by comparing video images, aerial images taken just after the eruption, and the observation of the deposits at the study site.

\section{Background of the Kuchinoerabujima volcano}

The Kuchinoerabujima volcano is an active volcano located on the volcanic front of the Ryukyu arc (Fig. 1). The Kuchinoerabujima volcano has a WNW-ESE elongated edifice. The height of the volcanic edifice is $\sim 1.2 \mathrm{~km}$ from the surrounding sea floor. The subaerial part of the Kuchinoerabujima volcano forms a volcanic island named Kuchinoerabu-jima, with a length of $12 \mathrm{~km}$ and a maximum height of $657 \mathrm{~m}$ above the sea level (Fig. 1).
The Kuchinoerabujima volcano is a cluster consisting of several volcanic edifices with different ages (Geshi and Kobayashi 2007). Shindake and Furudake, which seat at the central portion of the volcano (Fig. 1), are the active volcanic centers. Shindake is the youngest edifice and is comprised of andesitic lava flows which erupted $\sim 1000$ years ago (Miki et al. 2002). All historic eruptions since the middle of nineteenth century occurred from Shindake.

Shindake is characterized with its asymmetric topography. As Shindake sits near the center of the north-south trending ridge extending from Furudake to Noike, the eastern and western sides of Shindake show steep slopes which partially exceed $30^{\circ}$. The steep slopes coincide with the head of the Mukaehama River on the northwestern side and the Nanakama River on the eastern side. The northern and southern slopes of Shindake are, contrary, gentle slope toward Noike and Furudake.

Active geothermal areas and fumaroles at the summit of Shindake and Furudake indicate the presence of an active hydrothermal system within the volcanic edifice (Shinohara et al. 2011). The development of thick layers of explosive breccia with many hydrothermally altered components at the summits of Shindake and Furudake indicates frequent phreatic-phreatomagmatic explosive

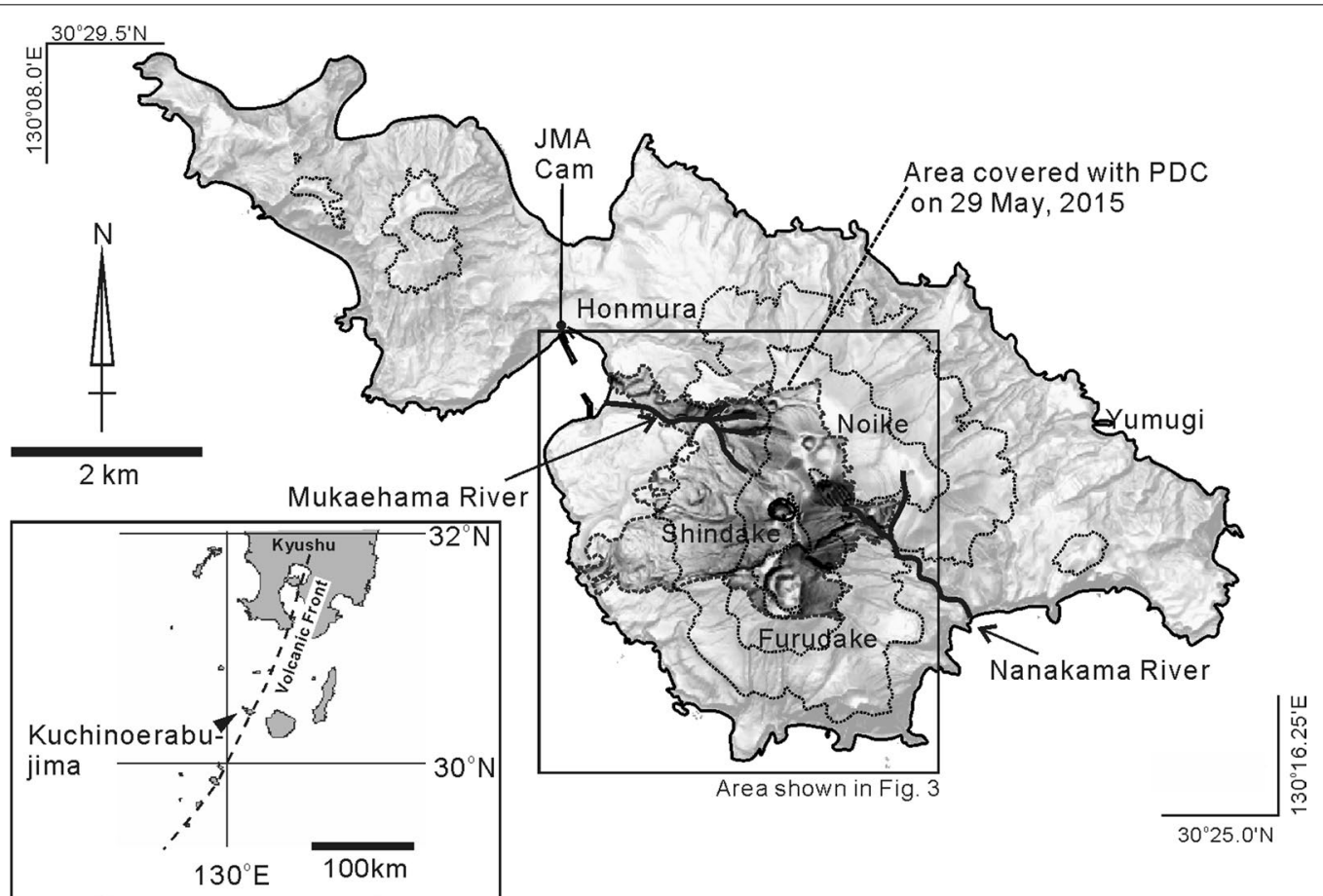

Fig. 1 Topographic map of the Kuchinoerabujima Island. The relief map was created using the 10-m-mesh digital elevation model provided by Geospatial Information Authority of Japan. The counters are at 200-m intervals. Mukaehama River and Nanakama River are shown with broad black lines. The shadowed area surrounded by dotted line represents the area covered by the pyroclastic density current (PDC). Locations of the monitoring camera operated by Japan Metrological Agency (JMA cam) are shown 
activities. The historical eruptions, which are limited within the last $\sim 200$ years, can be grouped into three active periods: the middle of the nineteenth century, the 1930s, and from 1966 to 1980 (Geshi and Kobayashi 2007). The ejecta of these eruptions mainly consists of rock fragments with various degrees of hydrothermal alterations and small amounts of fresh juvenile materials, indicating their phreatic-phreatomagmatic origin.

The population of the island is about 150 in 2010 AD. Most of the inhabitants live in the main village (Honmura) $\sim 3 \mathrm{~km} \mathrm{NW}$ of the main crater of Shindake.

\section{The 2014-2015 eruptions}

\section{Precursory activities}

The 2014-2015 eruptions were preceded by an intrusion event which activated the geothermal system. The inflation of the edifice between 1995-1996 and 2000, which is detected by the repeated GPS measurements, and the seismic swarm in 1999 suggests a magma intrusion beneath Shindake volcano in 1999 (Iguchi et al. 2007). Based on Mogi-model assumption, total inflation volume is estimated as $1.7 \times 10^{5} \mathrm{~m}^{3}$ at $\sim 0.1 \mathrm{~km}$ below sea level (Iguchi et al. 2017). After the intrusion event, the seismic activities in the edifice of Shindake were activated, reflecting the activation of the hydrothermal system in the edifice (Triastuty et al. 2009). A permanent GPS observation at the northwestern rim of the Shindake crater showed the episodic local inflation of the crater area. Timing of the inflation coincides with the rise of these seismic activities (Saito and Iguchi 2006; Iguchi et al. 2007). The depth of the pressure sources between February 2005 and January 2006, one of the inflation periods, is estimated as $200 \mathrm{~m}$ above sea level (Iguchi et al. 2017). The remarkable demagnetization in the shallow part of the Shindake crater was also detected during this period (Kanda 2007; Kanda et al. 2010).

Fumaroles in the summit area of Shindake were also activated with the rise of seismic activities and inflation of the volcanic edifice (Shinohara et al. 2011). The geothermal area at the summit of Shindake spread gradually from 2003 to 2006 (Iguchi 2007), with increasing the emission of volcanic gas from 2003 to 2009 (Shinohara et al. 2011). Opening of a new vigorous fumarole at the southern wall of the summit crater in October 2008 also shows the activation of the hydrothermal system within Shindake (Shinohara et al. 2011).

\section{Sequence of eruptions}

Three major eruptions and several minor ash emissions are recorded during the 2014-2015 activities. The first eruption occurred from the newly formed fissures in the eastern and western part of the summit crater of
Shindake (Geshi et al. 2016) on August 3, 2014 (Nakamichi et al. 2017). A minor pyroclastic density current (PDC) flowed along the western slope of the volcano and reached the coastal line $\sim 2.2 \mathrm{~km}$ from the crater. Intense fumarolic activities commenced after the 2014 eruption from the newly formed craters. The fumarolic activity peaked in early 2015, emitting 3000 ton/day of sulfur dioxide gas (Mori et al. 2017). Emission of diluted ashladen plume during this period also supports the occurrence of minor eruptive activities.

The eruption on May 29, 2015, is the largest event within the series of the activities from 2014 to 2015. The eruption occurred at 9:59 local time on May 29 from the Shindake summit crater (Nakamichi et al. 2017). The eruption started with a strong explosion. The seismic and the infrasonic records show major explosive pulses lasted within $5 \mathrm{~s}$ after the onset of the eruption (Nakamichi et al. 2017). The explosion scattered ballistic blocks in an area within $\sim 2 \mathrm{~km}$ of the crater. The eruption column rose up to $\sim 9 \mathrm{~km}$ above the crater and drifted to the ESE direction (Tanaka and Iguchi 2016). One inhabitant who was involved in the marginal portion of the PDC was injured in the Mukaehama area (Fig. 2).

Another eruption occurred on June 19, 2015 (Nakamichi et al. 2017), and the eruption column drifted to the ENE direction. Owing to the bad weather conditions and the damage to the monitoring system by the explosive eruption on May 29, the details of this eruption are unknown. Small ash emissions are also observed on June 20.

\section{Pyroclastic density currents of the May 29, 2015 eruption \\ Observations}

A monitoring camera at $3 \mathrm{~km} \mathrm{NW}$ of Shindake operated by the Japan Meteorological Agency (Fig. 1) recorded the details of the PDC which flowed along the northwestern slope of Shindake. The image showed that the jet of pyroclastic materials appeared from the crater rim at 09:59'39". The jet turned to an eruption column which rose from the summit crater of Shindake immediately after the onset of the eruption (Fig. 2A). A part of the eruption column also collapsed to generate the PDC which ran down along the slope (Fig. 2B). The front of the PDC appeared at the base of the eruption column from 09:59'57", $18 \mathrm{~s}$ after the onset of the eruption and migrated along the slope. The PDC spread on the western flank of Shindake formed several blanches (Fig. 2C). The PDC flowed $\sim 2.4 \mathrm{~km}$ along the valley of the Mukaehama River and reached the coastal line at around 10:00' $52^{\prime \prime}$, $75 \mathrm{~s}$ after the onset of the eruption (Fig. 2D). These photographs show significant outflow to west and northwest; 

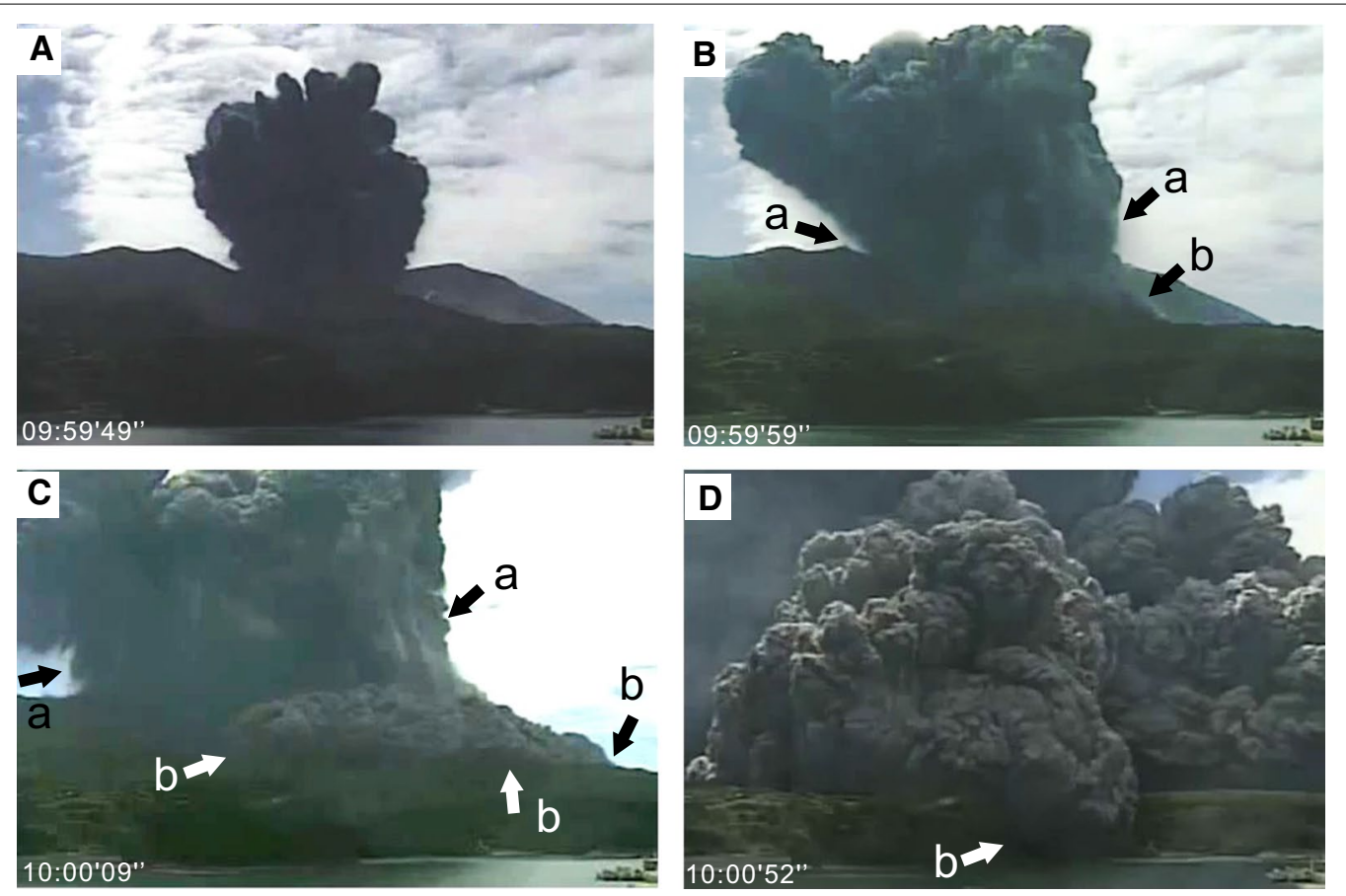

Fig. 2 Snapshots of the PDC from the monitoring camera located $3 \mathrm{~km} \mathrm{NW}$ of Shindake operated by Japan Meteorological Agency (A-D). Location of the camera is shown in Fig. 1. A $10 \mathrm{~s}$ after the onset of the eruption $\left(9: 59^{\prime} 49^{\prime \prime}\right)$. Pyroclastic materials ejected as jet and form rising eruption column. B $20 \mathrm{~s}$ after the onset of the eruption $\left(9: 59^{\prime} 59^{\prime \prime}\right)$. A part of the eruption column is collapsing (a). The front of the PDC can be recognized at the foot of the eruption column (b). C $30 \mathrm{~s}$ after the onset of the eruption $\left(10: 00^{\prime} 09^{\prime \prime}\right)$. The migrating front of PDC is indicated by arrows (b). D $75 \mathrm{~s}$ after the onset of the eruption (10:00'52'). The front of PDC (b) reached the beach of Mukaehama

however, there are minor outflows in all direction. The average speed of the PDC is $42 \mathrm{~m} / \mathrm{s}$. The ash-rich plume rose from the area covered by the PDC and then drifted southwestward.

\section{Distribution of PDC}

Distribution of the PDC (Fig. 3) was reconstructed by comparing the video images of the PDC with several aerial images obtained within 1 week from the eruption. The area covered with the PDC is recognizable as the region showing various types and degrees of damages observed mainly in the forest vegetation. The outer margin of the discolored area is commonly sharp and can be clearly identified (Fig. 4A). Distribution of the discolored vegetation is consistent with the area covered with pyroclastic flow in the video image. In contrast, remarkable damage to the vegetation was not observed in the area covered only with the ash-fall deposit from the eruption column.

Although the PDC flowed toward all directions from the summit (Fig. 3), three major flows are distinct, i.e., in the northwest direction along the Mukaehama River, in the southwest direction along some minor valleys, and a smaller flow occurred in the eastern direction along the Nanakama River. Among them, the flow along the Mukaehama River is the longest and can be traced for $\sim 2.4 \mathrm{~km}$ along the river to the coastal line.

The area suffered from the PDC is classified into five zones ranging from "a" to "e" in descending order (Fig. 3), corresponding to the thickness of the deposit and the degrees of the damage to the vegetation (Fig. 4A).

Zone a is the proximal area of the source crater, $<500 \mathrm{~m}$ from the rim of the source crater. The area is covered with thick and coarse pyroclastic deposit including large blocks (Fig. 4B). Thickness of the deposit in this zone was estimated $>1 \mathrm{~m}$ judging from the aerial photographs though it is poorly confirmed. The original vegetation less than $0.5-1 \mathrm{~m}$ height was completely destroyed and covered by the deposit in Zone a. Because Zone a distributes in the vicinity of the source crater, the pyroclastic deposit in Zone a consists of the mixture of ballistic blocks, fallout materials, and the deposit from PDC.

Zone $\mathrm{b}$ surrounds Zone a and distributes mainly in the steep slope in the eastern and western side of Shindake. The original vegetation was completely removed by the blast of PDC, and the basement rocks of lava are exposed in Zone b (Fig. 4B). Though Zone b may be also covered with thin layer of volcanic ash after the eruption, the rainfall washed out the deposit immediately after the eruption. 


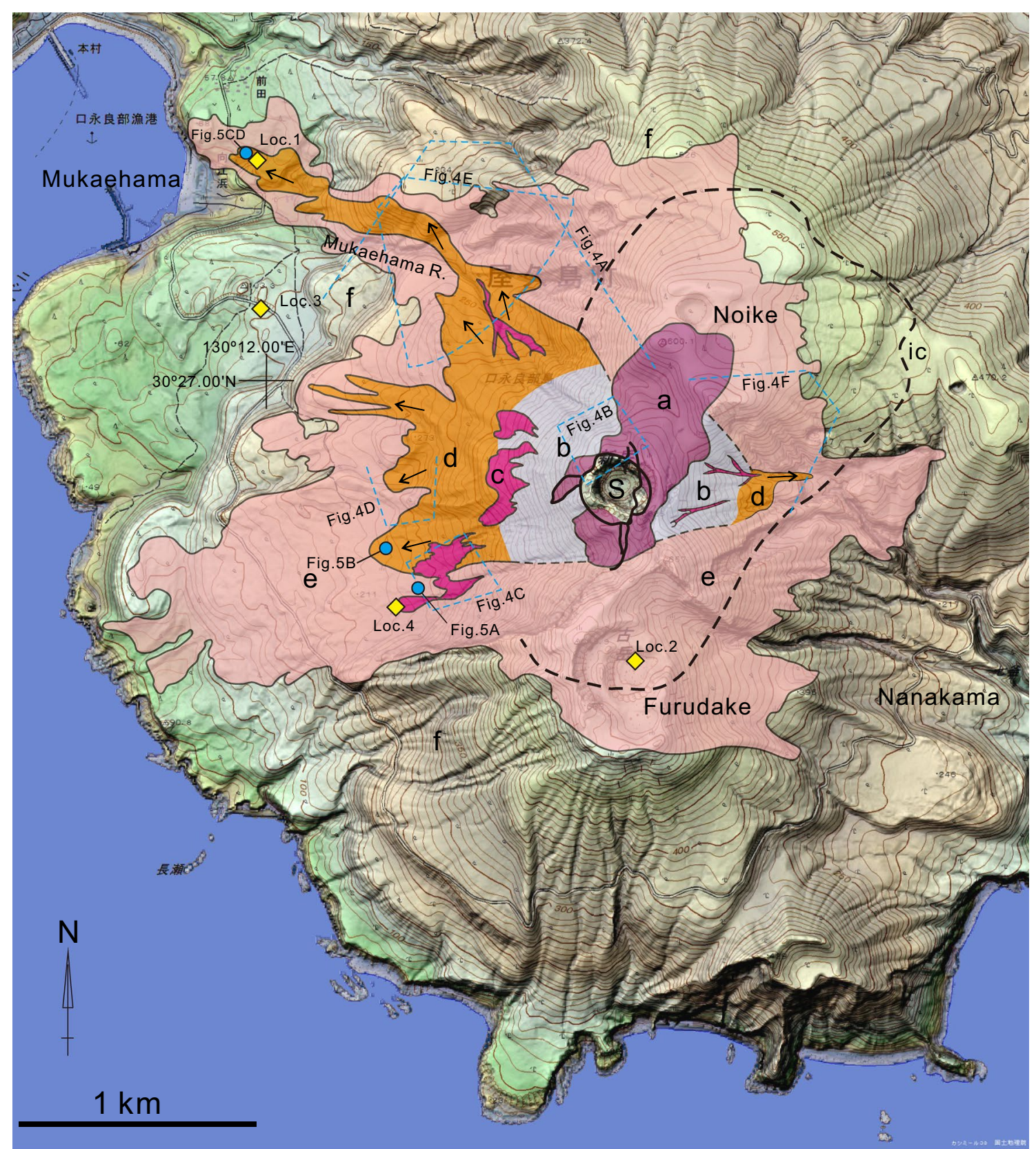
a zone a: proximal area covered with thick deposit of blocks.
b zone b: area covered with very-thin deposit. All vegitations were removed by PDC.
C zone c: area covered with thick block-and-ash flow deposit.
d zone d: area covered with thin ash layer from PDC. Trees are broken and fell by PDC blast.
e zone e: area covered with thin ash layer from PDC. Tree leaves and branches are broken by PDC blast.
f. zone f: area covered with thin ash-fall deposit

Fig. 3 Distribution of the pyroclastic density current on May 29, 2015. The summit crater of Shindake is indicated by "S."The area covered by the PDC is subdivided into "Zone a" to "Zone e" based on the thickness of the deposit and the degree of damage to the vegetation. The broken line signed with "ic" is the approximate limit of the dense distribution of impact craters (more than 10 craters per $100 \times 100 \mathrm{~m}$ area based on the aerial photographs). Blue broken lines show the area of the photographs shown in Fig. 4. Blue circles show the location of the photographs shown in Fig. 5. Diamond symbols indicate locations of the representative outcrops shown in Fig. 6 

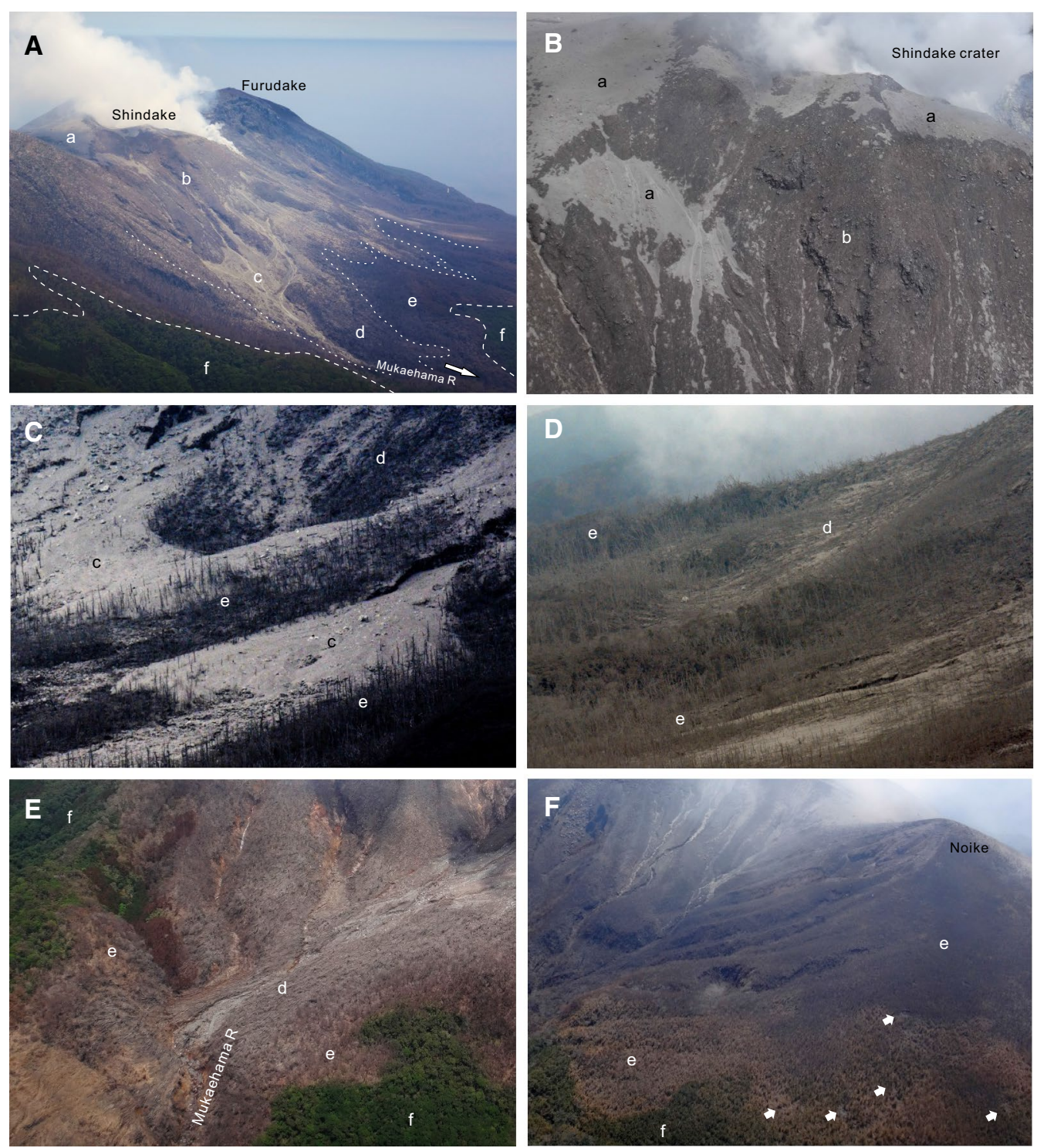

Fig. 4 Aerial view of the area affected by PDC. A Oblique aerial view of the northwestern side of Shindake. The area covered by the PDC is divided into Zone a to Zone e based on the distribution of the deposit and damage to the vegetation. Boundaries between Zones $\mathrm{d}$ and $\mathrm{e}$ and the outer limit of the Zone e are highlighted with broken lines. Zone f was not covered by the PDC. B Close-up view of the upper northwestern slope of Shindake taken on July 7, showing thick and coarse pyroclastic deposit including large block in Zone a and exposed basement rocks in Zone b. All the vegetations were removed in Zone b. C Close-up view of the fans of block-and-ash flow deposit at the southwestern flank of Shindake. D Trees swept by PDC in Zone d in the western flank of Shindake. Trees in Zone e were still standing but most of the leaves and blanches were lost. E Close-up view of the Mukaehama River showing the change of damage from Zone d (fallen trees)-Zone e (damaged vegetation)-Zone $\mathrm{f}$ (green vegetation). F Northeastern margin of the PDC. Discolored vegetations in Zone e and green vegetations in Zone fare shown. Arrows indicate major impact craters. The photographs $\mathbf{A}$ and $\mathbf{E}$ were taken on July 7; $\mathbf{B}$ and $\mathbf{F}$ are taken on June 1, 2015, by R. Kazahaya. C and $\mathbf{D}$ were taken on May 30 , 2015, by N. Geshi

Zone $\mathrm{c}$ is the area covered with coarse-grained pyroclastic deposit (Fig. 4C). Maximum thickness of the deposit in Zone c exceeds $1 \mathrm{~m}$. Zone c distributes mainly in the northwestern and southwestern flank of Shindake (Fig. 3). Deposit in Zone c is volcanic breccia which is characterized with the presence of large blocks of lava fragments more than $30 \mathrm{~cm}$ in diameter. Though most trees were broken and fell down in Zone c, many standing trees were buried in Zone $\mathrm{c}$ in the southwestern flank of Shindake (Fig. 4C).

Zone $\mathrm{d}$ is the area covered with thin pyroclastic deposit, which mainly consists of lapilli and volcanic 
ash with coarse-grained sand size. Zone $d$ was elongated along the main valleys and went straight through over minor ridgelines and slopes. The thickness of deposit in Zone $\mathrm{d}$ is typically less than $10 \mathrm{~cm}$. In Zone d, most trees were broken and fell by the PDC blast (Fig. 4D, E).

Zone e is the outermost part of the area covered with the PDC. The deposit in Zone e mainly consists of lapilli and volcanic ash with coarse-grained sand size. Very thin ash deposit $(<5 \mathrm{~cm})$ is typically found in Zone e. Though most of the trees kept standing, their leaves and fine branches of trees were partially broken and removed (Fig. 4E). The leaves of trees have been completely browned in this zone.

Zone $f$ is outside of the area covered with PDC and covered by the ash fall. The leaves of the trees in Zone $\mathrm{f} \mathrm{kept}$ greenish color (Fig. 4E). No mechanical damage by PDC on the vegetation was found in this zone. Thin deposits of very fine ash are found in Zone $f$.

Besides the damage by PDC, impact craters of ballistic blocks are found within $\sim 2 \mathrm{~km}$ from the source crater (area "ic" in Fig. 3). Particularly, many impact craters distribute in the northern side of Shindake (Fig. 4F).

\section{Damages}

The PDC caused mechanical damages due to the dynamic pressure of the blast and also thermal damages due to the hot materials contained in the PDC. The mechanical damages caused by the blast were mainly found on the forest. All trees in the inner portion of the Zone $d$ were broken and falling toward the down-flow. In the peripheral part of the Zone d, most trees kept only main trunk and thick branches, whereas minor branches and leaves were completely lost (Fig. 5b). Several impact marks formed by the collision of pyroclastic fragments in the PDC were also found on the surface of trees and wood poles (Fig. 5c).

Thermal damage was also recognized in most areas covered with the PDC. Dieback of vegetation in the area covered by the PDC (Zones $\mathrm{d}$ and e) was characterized by the browned foliage. The uniform discoloration of the vegetation in the area covered with the PDC (Fig. 4) indicates that the dieback of the vegetation was caused chiefly by the thermal impact rather than the chemical damage (Efford et al. 2014). One inhabitant received a burn injury at the marginal portion of the PDC in Zone d in Mukaehama area (Fig. 3). Plastic plates attached on the electric wire pillar were deformed toward the downstream side of the PDC in the Zone $\mathrm{d}$ of the Mukaehama area (Fig. 5d). The plates were most deformed at the axial part of the PDC and the deformation degree decreased toward the marginal portion of the PDC. A nylon wire found in the deposit at Loc. 1 was also partially melted and deformed. These

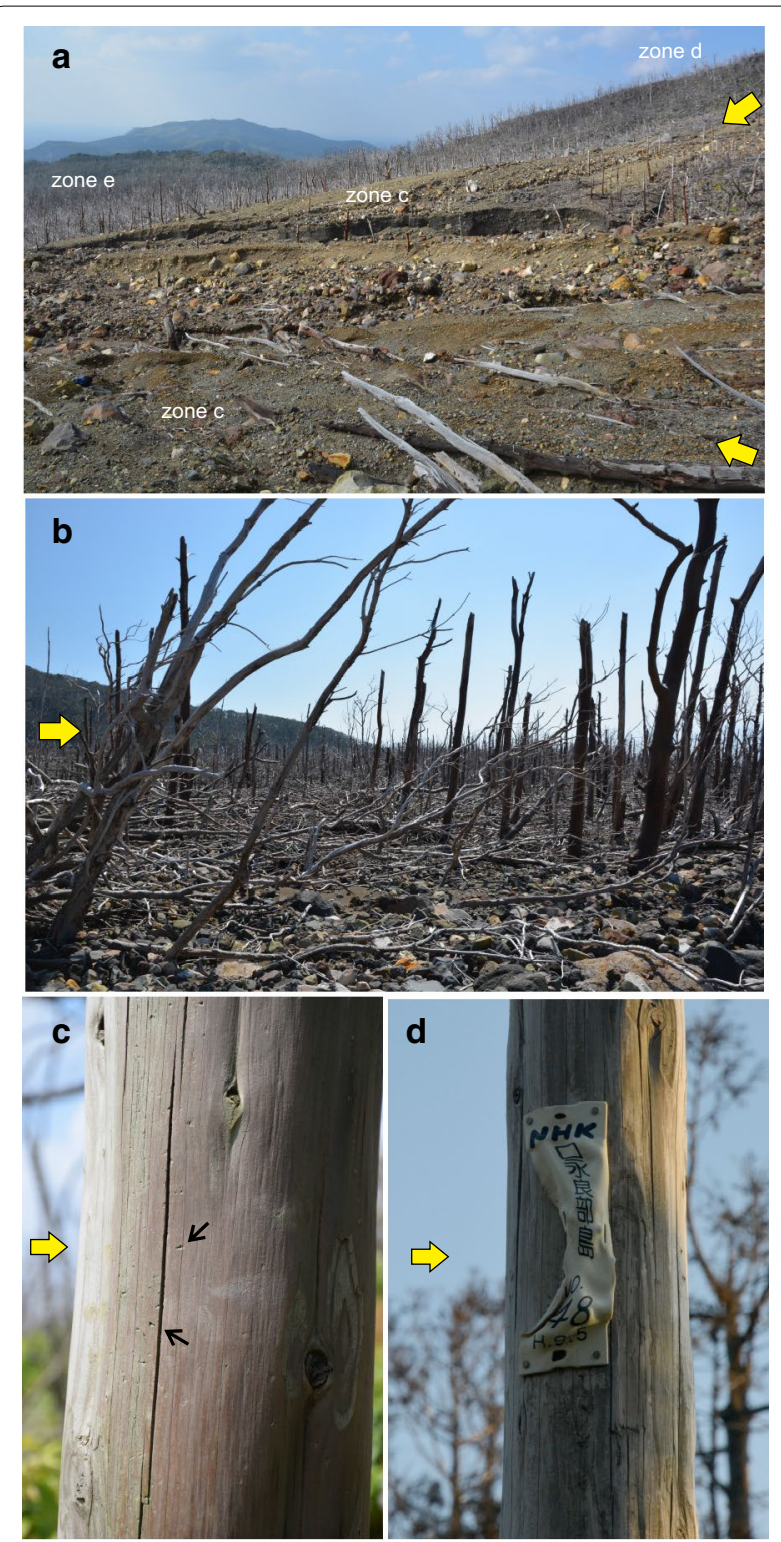

Fig. 5 The variation in the mechanical damages by PDC. Yellow arrow indicates the flow direction of the PDC in each location. a The western flank of Shindake, $1 \mathrm{~km}$ from the crater. The trees had fallen down and were buried by the block-and-ash flow deposit (Zone c). All trees in the right of the far field had fallen down toward the flank (Zone d). Most of trees in the left of the far field remained standing (Zone e). $\mathbf{b}$ The trees broken and fallen down by the blast of the PDC in the western flank of Shindake, $1 \mathrm{~km}$ from the crater. c Melted and deformed plastic plates on the electric pillar in Zone d. $\mathbf{d}$ Small impact pits on the wood pillar in Zone $\mathrm{d} \sim 2 \mathrm{~km}$ from the crater

evidences indicate that the PDC had enough temperature to make thermal effect on these items. However, these thermal effects were relatively limited comparing to magmatic PDC. No carbonized trees, except for an incomplete carbonization on the skin of a pine trees buried in the PDC deposit of Zone c, were found in 
the area covered by PDC. This was consistent with the absence of forest fire.

\section{Deposits}

Deposits of the PDC were divided into two types based on the thickness and lithofacies of the deposit. The first type, which characterizes most of the PDC deposit, is a thin layer of coarse-grained volcanic ash which was formed by the pyroclastic surge. The second type is a thick layer of poorly sorted volcanic breccia, which deposited from block-and-ash flows.

\section{Thin volcanic ash layer}

The first type of deposit is a layer consisting of volcanic ash and fine lapilli. This distributes in Zones $\mathrm{d}$ and e, which occupy $\sim 85 \%$ of the distribution area of the PDC. Figure $6 \mathrm{a}, \mathrm{b}$ shows the occurrence of the first type in Zone d (Mukaehama area: Loc. 1 in Fig. 3) and Zone e (the summit of Furudake: Loc. 2). Maximum thicknesses of the deposit at Mukaehama and Furudake, which is the peripheral part of Zones $\mathrm{d}$ and $\mathrm{e}$, are $\sim 4$ and $\sim 2 \mathrm{~cm}$, respectively. The thickness of the deposit is relatively constant at each locality, but locally thickened on the upwind
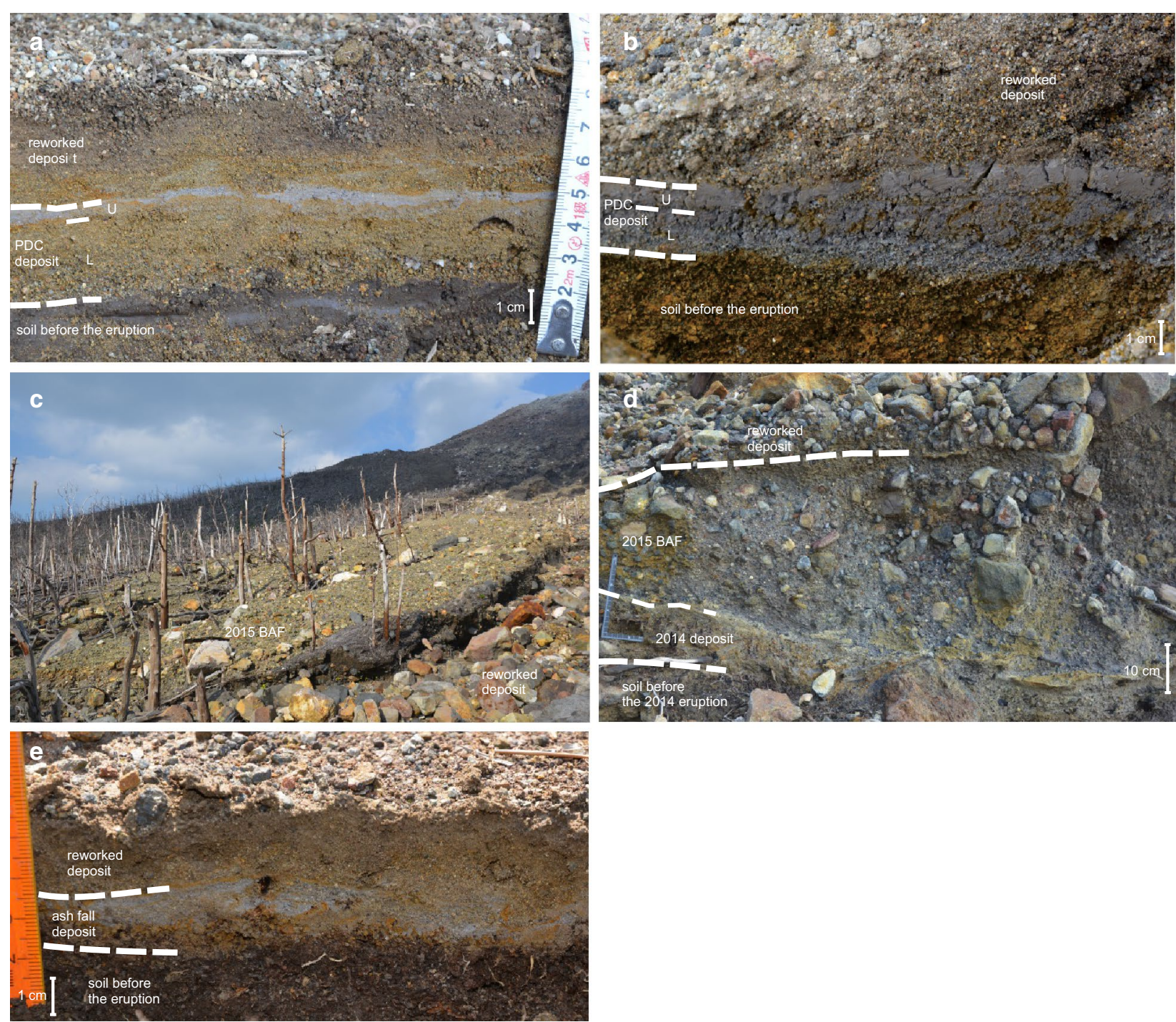

Fig. 6 a Deposit of the PDC in Zone d 2 km from the crater (Loc. 1). Photograph was taken in November 2016, 1.5 years after the eruption. The deposit is subdivided into $L$ and $U$ parts. $L 1, L 2$, and $U$ indicate the level of sampling for grain-size analysis. b Deposit of the PDC in Zone e, 1 km from the crater (Loc. 2). Photograph taken in March 2017. The deposit is divided into the normal-grading volcanic sand layer in the lower portion (L) covered by the fine grained volcanic ash (U). c Block-and-ash flow deposit at Loc. 4, 1 km from the crater. Photograph taken in March 2017. The deposit exhibits yellowish color in March 2017, 1.5 years after the eruption due to the surface weathering of the materials. $\mathbf{d}$ Cross section of the block-and-ash flow deposit of the PDC in Zone c (Loc. 4). Photograph taken in March 2017. The deposit overlies the 2014 tephra which contains plenty of plant fragments. e Ash-fall deposit in Zone $\mathrm{f}$ (Loc. 3). The level for sampling for grain-size analysis is indicated by bar with " $\mathrm{F"}$ 
side of the obstacles. No remarkable dune or ripple structure is recognized in the deposit. These deposits are also recognized in the underfloor space of the buildings and the insides of roofed bunkers, suggesting lateral transportation. Widely spread and thin distribution of the deposit indicates that this deposit was formed by a pyroclastic surge which is characterized with diluted flow.

The deposit exhibits upward-fining grading from fine lapilli at the base of the deposit to medium sand toward the top, with fine volcanic ash at the uppermost part of the deposit in both localities 1 and 2. In the median diameter $(M d \phi)$ versus sorting coefficient $(\sigma \phi)$ diagram (Walker 1983), the deposits were plotted within the area of "pyroclastic surge deposit" (Fig. 7). The deposits contained many fragments of woods and leaves, probably incorporated during the transportation of PDC.

A thin deposit of lapilli-free, consisting of volcanic sand, was also recognized in the outermost part of PDC (Zone e) where the mechanical damage on the trees was weak. Thickness of the deposit was less than $1 \mathrm{~cm}$ at Loc. 3 in the western flank of Shindake.

\section{Thick breccia deposit}

The thick layer of volcanic breccia mainly distributes in Zone c (Fig. 6c, d). The deposit consists of poorly sorted mixture of blocks of lavas, lapilli, and volcanic ash. The deposit exhibits matrix-supported structure without clear bedding structure (Fig. $6 \mathrm{~d}$ ). The maximum thickness of the deposit exceeds 2 meters. The thick breccia forms valley-fill deposit in some gullies on the slope of Shindake and also forms fans at the exit of these gullies in

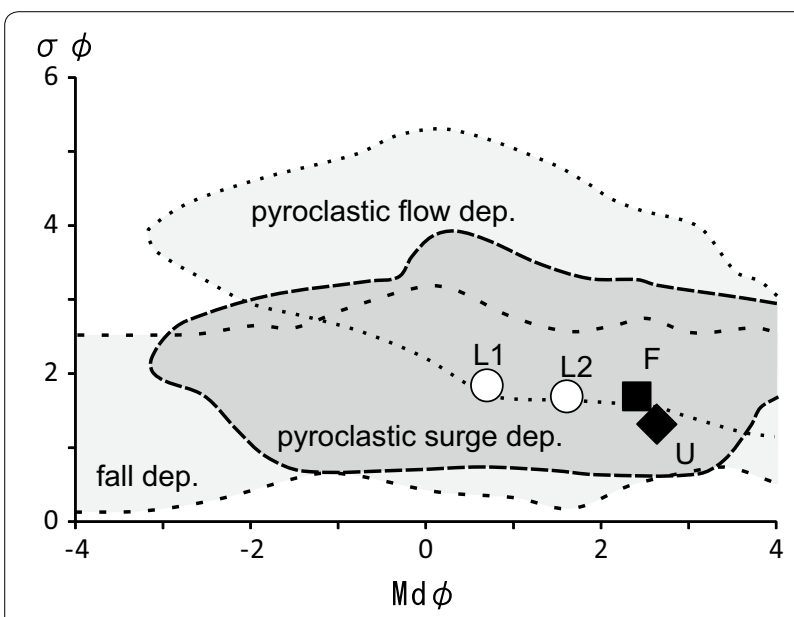

Fig. 7 Median diameter $(M d \varphi)$ versus sorting coefficient $(\sigma \varphi)$ for the PDC deposit collected from the Mukaehama area at the end of the northwestern lobe of the PDC. L1 and L2, lower part of Loc. 1; U, upper part of Loc. 1; F, fall deposit of Loc. 3. Sampling levels are shown in Fig. 6a, d. The areas for each deposit type are after Walker (1983) the western flanks of Shindake (Fig. 4C). The fan consists of a cluster of branching lobes. Individual lobe at Loc. 4 is 3-6 $\mathrm{m}$ in width, several $10 \mathrm{~s}$ meters in length and maximum $1 \mathrm{~m}$ in thickness (Fig. 6c). Large blocks were concentrated on the top and the tip of the lobe (Figs. 4C, 6c). The deposit consists of the fragments of lava with various degrees of hydrothermal alteration. Trees buried in the lobes remained upright, particularly in the marginal portion of the deposit (Fig. 6c). The valley-fill distribution, fan-formation and poorly sorted massive structure of the breccia support that they were produced from high-density block-and-ash flow. Though Zone a is also covered with coarse-grained thick deposit, their detailed lithofacies and structure are still unknown because of the lack of field observation in the proximal area of the active crater.

\section{Total mass of the PDC deposit}

Total volume of the PDC deposits was evaluated on the basis of their distribution. In Fig. 3, the area covered by the PDC was estimated to be $5.2 \mathrm{~km}^{2}$. The PDC deposits were distributed in the Zones c, d, and e (Fig. 3).

The average thicknesses in the Zones e, $\mathrm{d}$, and c are assumed from field observation as $0.01,0.05$, and $1.0 \mathrm{~m}$, respectively, and the volumes of the PDC deposit were also calculated as $1.1 \times 10^{5}, 3.8 \times 10^{4}$, and $3.6 \times 10^{4} \mathrm{~m}^{3}$, respectively. The total mass of the PDC deposit was calculated by employing the average density of the deposit in dry condition to be $1500 \mathrm{~kg} \mathrm{~m}^{-3}$ for Zones a and c, and $1000 \mathrm{~kg} \mathrm{~m}^{-3}$ for Zones $\mathrm{d}$ and e, based on the measurement of the block-and-ash deposit at Loc. 4 in Fig. 3 $\left(1520 \mathrm{~kg} / \mathrm{m}^{3}\right)$ and the thin-ash deposit at Loc. 1 (995$1045 \mathrm{~kg} / \mathrm{m}^{3}$ ). The total mass of the PDC deposit was evaluated to be $2.4 \times 10^{8} \mathrm{~kg}$, including $1.7 \times 10^{8} \mathrm{~kg}$ for the block-and-ash flow deposit in Zone c and $7 \times 10^{7} \mathrm{~kg}$ for pyroclastic surge deposit in Zones $\mathrm{d}$ and $\mathrm{e}$.

The proximal deposit distributed in the Zone a was evaluated as $5.0 \times 10^{8} \mathrm{~kg}$, assuming that the deposit with $1 \mathrm{~m}$ and $1500 \mathrm{~kg} / \mathrm{m}^{3}$ covers an area $0.33 \mathrm{~km}^{2}$. The combined analysis of the numerical simulation of volcanic ash plume and the ground survey of the ash-fall deposit suggests that the ash cloud contained $\sim 6 \times 10^{8} \mathrm{~kg}$ of ash particles (Tanaka and Iguchi 2016). The total mass of the erupted materials from the May 29 eruption was thus estimated as $\sim 1.3 \times 10^{9} \mathrm{~kg}$.

\section{Components}

We investigated particle components of the thin volcanic ash layer formed by the pyroclastic surge, the thick breccia deposits, and the ash-fall deposit. Samples were collected from the Mukaehama area (Loc. 1 in Fig. 3), the western flank of Shindake (Loc. 4 in Fig. 3), and in the Zone $\mathrm{f}$ in the western flank of Shindake (Loc. 3 in Fig. 3). 
The coarser grains $(>2 \mathrm{~mm}$ ) were investigated under the optical microscope.

Hydrothermally altered whitish rock fragments occupied more than half of the coarser grains of all deposits. They were subdivided into silicified dense rock fragments and porous fragments consisting of sulfide, clay, and silicate minerals. The fragments of crystalline lavas derived likely from the vent wall were also recognized. Some fragments exhibited a pink coloring due to oxidization.

Small amounts of least-altered fragments of lava were also recognized in these deposits. The grains had an angular outline surrounded by brittle-fractured surfaces. These grains exhibit grayish color and had semi-glossy surfaces when observed under the optical microscope. Some grains also had microcracks on the surface. The interior of these grains was highly crystallized. These grains contained plagioclase, orthopyroxene, magnetite, and tridymite as the groundmass minerals. The groundmass glass remained in tiny interstices between the crystals. Some groundmass glasses also contained microbubbles.

The fine components $(<63 \mu \mathrm{m})$ of the PDC deposits were analyzed with an X-ray diffractometer (XRD) installed at the Geological Survey of Japan. The XRD analysis identified that the major components of the PDC deposits are natroalunite, jarosite, crystallite, and tridymite, as well as the dominant plagioclase, which is a representative mineral of fresh volcanic rock. Under the optical microscope, pyrite crystals were also found.

These observations indicate that the PDC deposits contain abundant blocky rock fragments with various degrees of hydrothermal alterations. The presence of hydrothermally altered minerals and the absence of vesiculated juvenile materials in these PDC deposits indicate that the 2015 eruption occurred from the hydrothermal system sealed inside the edifice of Shindake. The mineral assemblage of the hydrothermally altered minerals indicates low $\mathrm{pH}$ environment of the hydrothermal system.

The PDC deposit exposed on the ground surface was weathered rapidly after the eruption. The sulfide minerals in the hydrothermally altered materials in the deposit can be broken down to generate ferrihydrite minerals and gypsum under such ground surface condition. In fact, the PDC deposit, originally grayish color just after the eruption, turned brownish in color owing to the precipitation of the secondary ferrihydrite $\sim 1.5$ years after the eruption.

\section{Discussion}

\section{Cause of the PDC}

The PDC of the May 29, 2015 eruption was characterized with the lateral pyroclastic surge which covered wide area of the flank of the volcano. The video records show that the eruption was characterized by a shortlived explosive ejection of the pyroclastic materials. Seismic and infrasonic data also indicate that the major explosive pulses lasted within $5 \mathrm{~s}$ after the onset of the eruption (Nakamichi et al. 2017). However, the video image recorded by JMA monitoring camera shows that the appearance of the PDC behinds $\sim 18 \mathrm{~s}$ from the onset of the eruption (Fig. 2B). The images of the monitoring camera show the partial collapse of the eruption column before the onset of the PDC (Fig. 2B). Generation of PDC by laterally directed explosion (e.g., Wohletz 1998) is inconsistent with the presence of clear time gap between the major explosion and the occurrence of the PDC. The distribution of the PDC in all direction from the crater (Fig. 3) is also negative for the directed explosion because laterally directed ejection may cause an asymmetric distribution of PDC reflecting the direction of the ejection (e.g., Te Maari eruption, Mt. Tongariro; Lube et al. 2014). Moreover, the eruption occurred from the bottom of the summit crater of Shindake, which surrounded by $>50 \mathrm{~m}$ height vertical wall. Laterally directed blast from the crater bottom might be blocked by the crater wall and difficult to eject beyond the crater rim to produce PDC flow down to the flank.

The PDC seems to come out just after the eruption column collapsed (Fig. 2B, C). Distribution of the major flow of the PDC also supports the column-collapse origin of the PDC. Though one may point out that PDC has branches directing to at least NW, SW, and E, such a branching takes place at a certain part of the slope $(\sim 200 \mathrm{~m}$ asl in the western flank and $\sim 400 \mathrm{~m}$ in the eastern flank), where deep and steep valley angle of which exceeds $30^{\circ}$ appears. We thus would like to conclude that the PDC was originally flow down in all direction but branched controlled by the topography. The fallout materials collapsed from the eruption column could not stay on the steep slope and slipped down to produce PDC toward E, NW and SW directions. Lack of the deposit in Zone b (Fig. 4B) supports the idea that the materials slipped down from the steep slope owing to the instability of the deposit. Acceleration of PDC on the steep slope may diminish deposition of the particles on the slope (e.g., Martin and Nokes 1988) and may also promote the formation of prominent flows at the foot of slope.

The PDCs flowed northern and southern flank of Shindake where slope is gentle $\left(<20^{\circ}\right)$ were short in length but developed thick deposit represented as Zone a. Development of thick deposit in Zone a in the northern and southern sides of the Shindake summit crater (Figs. 3, 4B) indicates that most part of the fallout 
materials could stay on the gentle slopes to form thick deposit in Zone a, and therefore, minor PDCs were produced from these slopes.

\section{Temperature of the PDC}

Lack of evidence for exposure of vegetation to high temperatures environment, such as carbonization of wood and the occurrence of forest fires in the depositional area of the PDC, indicates that the temperature of the PDC was probably lower than the ignition temperature of dry wood which is typically around $240-270{ }^{\circ} \mathrm{C}$. This estimated temperature is much lower than that of the magmatic PDC, which commonly exhibit $>300{ }^{\circ} \mathrm{C}$ (e.g., Giordano et al. 2018). The relatively low temperature of the PDC is consistent with the fact that the PDC deposit was mainly composed of non-juvenile materials such as hydrothermally altered rock fragments.

However, some thermal damages observed in the area: the burn injury of an inhabitant, dieback of all leaves of the plants, and melting of some plastic products. These indicate that the temperature of the PDC was significantly higher than the environmental temperature. Higher temperature was also detected by the thermal infrared image taken immediately after the eruption (Uhira and Toriyama 2015).

The dieback of most vegetation in the PDC depositional area suggests that the temperature reached above $\sim 60^{\circ} \mathrm{C}$, though this estimation of the temperature depends on the species of vegetation and the duration of the exposure (Efford et al. 2014). The deformed and melted nylon materials in the PDC area indicate that the temperature in the PDC was higher than the softening temperature of nylon, which is around $180^{\circ} \mathrm{C}$.

Relatively well-sorted features of the surge deposit suggest that the deposits were driven and settled in a dry state without any significant aggregation. Uhira and Toriyama (2015) also reported that the PDC deposit at around Loc. 1 in Fig. 3 was "dry and powdery ash" immediately after the settlement. These facts indicate that the temperature in the PDC could exceed far more than the water-boiling temperature. These facts suggest that the temperature in the PDC can be between the boiling temperature $\left(100{ }^{\circ} \mathrm{C}\right)$ and the ignition temperature of the woody materials $\left(240-270{ }^{\circ} \mathrm{C}\right)$. This estimated temperature and the dynamic pressure of the PDC is fatal for humans if they are involved in the current.

\section{Conclusions}

The explosive phreatomagmatic eruption of Kuchinoerabujima on May 29, 2015, produced relatively low temperature pyroclastic density currents (PDC) which reached a maximum distance of $2.4 \mathrm{~km}$ from the source crater. Partial collapse of the eruption column on the steep slope of Shindake edifice caused the PDC.

The PDC of the 2015 eruption is characterized with surge deposits associating with small volume of blockand-ash flow deposits. More than $80 \%$ of the spread area of PDC was covered with the pyroclastic surge deposit, typically less than $5 \mathrm{~cm}$ in thickness. Low contribution of magmatic juvenile materials in the PDC deposit resulted relatively low temperature of the flow.

The PDC caused mechanical damages due to the dynamic pressure and thermal damages due to the high temperature. Broken trees along the course of the PDC are consistent with the estimated flow speed more than $40 \mathrm{~m} / \mathrm{s}$. Dieback of all leaves of the vegetation and the melting plastic materials suggest that the maximum temperature of the PDC ranges between the boiling temperature of water $\left(100{ }^{\circ} \mathrm{C}\right)$ and ignition temperature of wood $\left(240-270{ }^{\circ} \mathrm{C}\right)$. Though the size of the PDC caused by phreatic eruptions was small and the temperature relatively low, the dynamic pressure and temperature of the PDC were highly hazardous for humans.

\section{Abbreviations \\ PDC: pyroclastic density current; XRD: X-ray diffractometer.}

\section{Authors' contributions}

Field surveys in Kuchinoerabujima were carried out by both authors. NG carried out the aerial photograph interpretation to produce the distribution map of the PDC. II carried out the XRD analysis. Both authors read and approved the final manuscript.

\section{Acknowledgements}

Japan Meteorological Agency supported our field survey. Ryunosuke Kazahaya provided the aerial images. We are grateful to Masato Iguchi, Haruhisa Nakamichi, and Hiroshi Shinohara for scientific support. We also acknowledge Shojiro Nakagawa for his support during the field surveys. Two anonymous reviewers and the editor provide constructive suggestions on the manuscript. This work was supported by MEXT KAKENHI No. $15 \mathrm{H} 05794$.

\section{Competing interests}

The authors declare that they have no competing interests.

Availability of data and materials

Not applicable.

Consent for publication

Not applicable.

Ethics approval and consent to participate

Not applicable.

Funding

This work was supported by MEXT KAKENHI No. $15 \mathrm{H} 05794$.

\section{Publisher's Note}

Springer Nature remains neutral with regard to jurisdictional claims in published maps and institutional affiliations.

Received: 7 August 2017 Accepted: 22 June 2018

Published online: 11 July 2018 


\section{References}

Efford JT, Bylsma RJ, Clarkson BD, Pittari A, Mauriohooho K, Moon VG (2014) Vegetation dieback as a proxy for temperature within a wet pyroclastic density current: a novel experiment and observation from the 6th of August 2012 Tongariro eruption. J Volcanol Geotherm Res 286:367-372

Fujinawa A, Ban M, Ohba T, Kontani K, Miura K (2008) Characterization of lowtemperature pyroclastic surges that occurred in the northeastern Japan arc during the late 19th century. J Volcanol Geotherm Res 178:113-130. https://doi.org/10.1016/j.jvolgeores.2008.07.004

Geshi N, Kobayashi T (2007) Geological Map of Kuchinoerabujima Volcano (1:25,000). Geological Map of Volcanoes 14, Geological Survey of Japan AIST, Tsukuba (in Japanese with English abstract)

Geshi N, Iguchi M, Shinohara H (2016) Phreatomagmatic eruptions of 2014 and 2015 in Kuchinoerabujima Volcano triggered by a shallow intrusion of magma. J Nat Disaster Sci 37:67-78

Giordano G, Zanella E, Trolese M, Baffioni C, Vona A, Caricchi C, Benedetti AA Corrado S, Romano C, Sulpizio R, Geshi N (2018) Thermal interactions of the AD79 Vesuvius pyroclastic density currents and their deposits at Villa dei Papiri (Herculaneum archaeological site, Italy). Earth Planet Sci Lett 490:180-192

Iguchi M (2007) Volcanic activity at Kuchinoerabujima volcano in 2006. DPRI, Kyoto University, Kyoto, pp 1-8 (in Japanese)

Iguchi M, Saito E, Suzuki A (2007) Repeated GPS measurements at Kuchinoerabujima volcano during the Period from 1995 to 2006. DPRI, Kyoto University, Kyoto, pp 33-40 (in Japanese)

Iguchi M, Nakamichi H, Tameguri T, Yamamoto K, Mori T, Ohminato T, Saito E (2017) Contribution of monitoring data to decision making for evacuation from the 2014 and 2015 eruptions of Kuchinoerabujima Volcano. J Nat Disaster Sci 38:31-47

Kanda W (2007) Recent geomagnetic field variations observed at Kuchi-erabujima volcano. DPRI, Kyoto University, Kyoto, pp 37-40 (in Japanese)

Kanda W, Utsugi M, Tanaka Y, Hashimoto T, Fujii I, Hasenaka T, Shigeno N (2010) A heating process of Kuchi-erabu-jima volcano, Japan, as inferred from geomagnetic field variations and electrical structure. J Volcanol Geotherm Res 189:158-171

Kobayashi M, Mannen K, Okuno M, Nakamura T, Hakamata K (2006) The Owakidani Tephra group: a newly discovered post-magmatic eruption product of Hakone volcano, Japan. Bull Volcanol Soc Jpn 51:245-256 (in Japanese with English abstract)

Lube G, Breard ECP, Cronin SJ, Procter JN, Brenna M, Moebis A, Pardo N, Stewart RB, Jolly A, Fournier N (2014) Dynamics of surges generated by hydrothermal blasts during the 6 August 2012 Te Maari eruption, Mt.
Tongariro, New Zealand. J Volcanol Geotherm Res 286:348-366. https:// doi.org/10.1016/j.jvolgeores.2014.05.010

Martin D, Nokes R (1988) Crystal settling in a vigorously convicting magma chamber. Nature 332:534-536

McPhie J, Walker GPL, Christiansen RL (1990) Phreatomagmatic and phreatic fall and surge deposits from explosions at Kilauea volcano, Hawaii, 1790 a.d.: Keanakakoi Ash Member. Bull Volcanol 52:334-354

Miki D, Iguchi M, Eto T, Solihin A (2002) Paleomagnetic ages of the lava flows of Shindake, Kuchinoerabujima. DPRI, Kyoto University, Kyoto, pp 159-168 (in Japanese)

Mori T, Morita M, Iguchi M, Fukuoka Regional Headquarters JMA (2017) Sulfur dioxide flux monitoring using a regular service ferry after the 2014 eruption of Kuchinoerabujima Volcano, Japan. J Nat Disaster Sci 38:105-118

Nakamichi H, Masato I, Taneguri T, Sonoda T (2017) Quantification of seismic and acoustic waves to characterize the 2014 and 2015 eruptions of Kuchinoerabujima Volcano, Japan. J Nat Disaster Sci 38:65-83

Oikawa T, Yoshimoto M, Nakada S, Maeno F, Komori J, Shimano T, Takeshita Y, Ishizuka Y, Ishimine $Y$ (2016) Reconstruction of the 2014 eruption sequence of Ontake Volcano from recorded images and interviews. Earth Planets Space 68:79. https://doi.org/10.1186/s40623-016-0458-5

Saito E, Iguchi M (2006) Ground deformation detection at Kuchinoerabujima Volcano by continuous GPS with simple atmospheric correction. Bull Volcanol Soc Jpn 51:21-30 (in Japanese with English abstract)

Shinohara H, Hirabayashi J, Iguchi M (2011) Evolution of volcanic gas composition during repeated culmination of volcanic activity at Kuchinoerabujima volcano, Japan. J Volcanol Geotherm Res 202:107-116

Tanaka HL, Iguchi M (2016) Numerical simulation of volcanic ash plume dispersal from Kuchinoerabujima on 29 May 2015. J Nat Disaster Sci 37:79-90

Triastuty $\mathrm{H}$, Iguchi M, Tameguri $\mathrm{T}$ (2009) Temporal change of characteristics of shallow volcano-tectonic earthquakes associated with increase in volcanic activity at Kuchinoerabujima volcano, Japan. J Volcanol Geotherm Res 187:1-12

Uhira K, Toriyama N (2015) Meeting with the May 29, 2015 eruption of Kuchinoerabujima volcano. Bull Volcanol Soc Jpn 60:487-490 (in Japanese with English abstract)

Walker GPL (1983) Ignimbrite types and ignimbrite problems. J Volcanol Geotherm Res 17:65-88

Wohletz KH (1998) Pyroclastic surges and compressible two-phase flow. In: Freundt A, Rosi M (eds) From magma to tephra. Elsevier, Amsterdam, pp 247-312

\section{Submit your manuscript to a SpringerOpen ${ }^{\circ}$ journal and benefit from:}

- Convenient online submission

- Rigorous peer review

- Open access: articles freely available online

- High visibility within the field

- Retaining the copyright to your article

Submit your next manuscript at springeropen.com 